\title{
Description of two new sympatric species of the genus Hisonotus Eigenmann and Eigenmann, 1889, from upper Rio Tapajós, Mato Grosso state, Brazil (Pisces: Ostariophysi: Loricariidae)
}

\author{
Britski, HA. ${ }^{\mathrm{a} *}$ and Garavello, $J C{ }^{\mathrm{b}}$

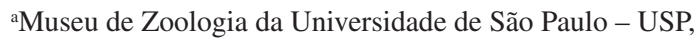 \\ Avenida Nazaré, 481, CP 42694, CEP 04299-970, São Paulo, SP, Brazil \\ bDepartamento de Ecologia e Biologia Evolutiva da Universidade Federal de São Carlos - UFSCar, \\ Rodovia Washington Luis, Km 235, CP 676, CEP 13565-905, São Carlos, SP, Brazil \\ *e-mail: heraldo@usp.br
}

Received June 23, 2005 - Accepted March 7, 2006 - Distribute August 31, 2007

(With 6 figures)

\begin{abstract}
Two new species of the genus Hisonotus are described from the upper Rio Tapajós basin, Mato Grosso State, Brazil. They are small species, growing up to about $30.0 \mathrm{~mm} \mathrm{SL}$, having the scapular bridge wide and totally exposed or having a small median pair of arrector fossae, and the abdomen completely covered with large plates in adult specimens (about $23.0 \mathrm{~mm} \mathrm{SL}$ ). They are distinguished from their congeners by the following combination of characters: Hisonotus chromodontus has 20-40 reddish-brown tipped premaxillary teeth, and 15-38 on the dentary bones; 23-24 plates on the longitudinal series; a prominent large dark brown lateral stripe extending from the tip of the snout to the caudal blotch; transversal dark brown bars very inconspicuous or absent. Hisonotus luteofrenatus has a moderate number (12-28) of hyaline or slightly yellow-tipped premaxillary teeth, and 9-26 on the dentary bones; 25-26 plates on the longitudinal series; a characteristic yellow line extending from the anterior part of each orbit, over the inferior nostril, both converging to the tip of the snout.
\end{abstract}

Keywords: Neotropical, freshwater fishes, systematics, Rio Tapajós, Brazil.

\section{Descrição de duas novas espécies simpátricas do gênero Hisonotus do alto Rio Tapajós, Estado do Mato Grosso, Brasil (Pisces: Ostariophysi: Loricariidae)}

\begin{abstract}
Resumo
Descrevem-se duas novas espécies de Hisonotus das cabeceiras do Rio Tapajós, Mato Grosso. São espécies de pequeno porte dentro do gênero, até cerca de $30 \mathrm{~mm} \mathrm{CP}$; os espécimes adultos possuem ponte escapular larga e totalmente exposta, ou deixando apenas um pequeno par de arrector fossae mediano, e abdome completamente coberto por placas grandes, em indivíduos adultos (acima de 23,0 mm CP). A combinação dos seguintes caracteres diferencia as novas espécies das demais do gênero. Hisonotus chromodontus n. sp. apresenta grande número de dentes de ponta castanhoavermelhada, 20-40 no pré-maxilar e 15-38 no dentário; 23-24 placas na série longitudinal; uma predominante listra lateral marrom-escura larga, que se estende da ponta do focinho, passando abaixo da órbita, até o fim do pedúnculo caudal; barras transversais ausentes ou muito inconspícuas. Hisonotus luteofrenatus n. sp. apresenta 12-28 dentes de ponta hialina ou levemente amarelada no pré-maxilar e 9-26 no dentário; 25-26 placas na série longitudinal; uma característica linha amarela estendendo-se da região anterior de cada órbita, passando na região inferior da narina e ambas convergindo para a ponta do focinho.
\end{abstract}

Palavras-chave: Peixes de água doce, Neotropicais, sistemática, Rio Tapajós, Brasil.

\section{Introduction}

The genus Hisonotus Eigenmann and Eigenmann, 1889, was resurrected and redefined by Schaefer (1998) as a member of the tribe Otothyrini of the Hypotopomatinae. Before that, we had already assembled large collections containing various new species of the genus we intended to describe from each of the Brazilian river basins where

they occur. Following this idea, we have recently described Hisonotus insperatus from the upper Rio Paraná basin (Britski and Garavello, 2003) and are also revising the species of the genus from the Southeastern Brazilian basins. In this article we study the Hisonotus species from the Rio Tapajós basin. Thirteen nominal species 
are included in Hisonotus: H. paulinus (Regan, 1908), H. depressinotus (Ribeiro, 1918), H. depressicauda (Ribeiro, 1918), H. francirochai (R. v. Ihering, 1928), and H. insperatus Britski and Garavello, 2003 all from the upper Rio Paraná basin; H. notatus (Eigenmann and Eigenmann, 1889), H. leucofrenatus (Ribeiro, 1908), H. nigricauda (Boulenger, 1891), H. laevior Cope, 1894, H. leptochilus Cope, 1894, and H. taimensis (Buckup, 1981) from southeastern and southern Brazilian drainages; and H. maculipinnis (Regan, 1912) and H. ringueleti Aquino, Schaefer and Miquelarena, 2001, from Río de La Plata (see Schaefer, 2003). The new species herein described from Rio Tapajós, Mato Grosso, are the first collected from a tributary flowing into the Amazon basin.

\section{Methods}

Measurements were taken with vernier calipers. Measurements and counts were taken on the left side of the specimens under a stereomicroscope following Britski and Garavello (1984). The standard length was taken from the snout tip to the beginning of the elongated plates covering the base of the caudal fin. Head length is from the tip of the snout to the upper angle of the branchial opening (not to the distal border of the supraoccipital, as is usually the case for some Loricariidae). Plates of the longitudinal series were counted from the series just posterior to the cleithrum (mid ventral series), shifting to the perforated plates of the lateral line (median series) along the caudal peduncle; the number of lateral-line plates in the lateral line was counted from cleared and stained specimens. Names of plates and plate series follow Schaefer (1997) and Britski and Garavello (2002). Rows of odontodes were counted from the median dorsal line to the median ventral line of the caudal peduncle, at vertical through base of the last anal-fin ray. Museum acronyms follow Leviton et al. (1985).

\subsection{Hisonotus chromodontus, new species (Figure 1, Table 1)}

Holotype: MZUSP 45355, 25.8 mm SL, $§$; Brazil: Mato Grosso State: Diamantino, creek number 1, tributary of Rio Preto, on road to São Francisco, Rio Arinos drainage (ca. $14^{\circ} 18^{\prime} \mathrm{S}$ and $56^{\circ} 20^{\prime} \mathrm{W}$ ); 24 October 1992 ; H. A. Britski, N. A. Menezes, O. T. Oyakawa and M. L. Triques.

Paratypes: Brazil, Mato Grosso State, Rio Arinos and Rio Teles Pires drainages: MZUSP 45315, 12, 1 C\&S, 20.0-28.0 mm SL, same data as holotype - MZUSP 70758, 7, 19.4-23.9 mm SL, Sinop, Riacho Loanda, tributary of Rio Teles Pires, ca. $54 \mathrm{~km}$ north of Sinop on the BR-163 road to Santarém ( $11^{\circ} 25^{\prime} \mathrm{S}$ and 55 21' W); 21 February 1998; M. I. Landim and C. Moreira - MZUSP 87145, 3, 1 C\&S, 19.2-20.8 mm SL, Sinop, Riacho Selma, ca. $38.4 \mathrm{~km}$ from Sinop, on the BR-163 road to Santarém ( $11^{\circ} 34^{\prime} \mathrm{S}$ and $\left.55^{\circ} 21^{\prime} \mathrm{W}\right)$; 22 February 1998; M. I. Landim and C. Moreira - MZUSP 61082, 7, 26.5-30.3 mm SL, Nova Mutum, unnamed creek at Fazenda Buriti, ca. $1.5 \mathrm{~km}$ south of

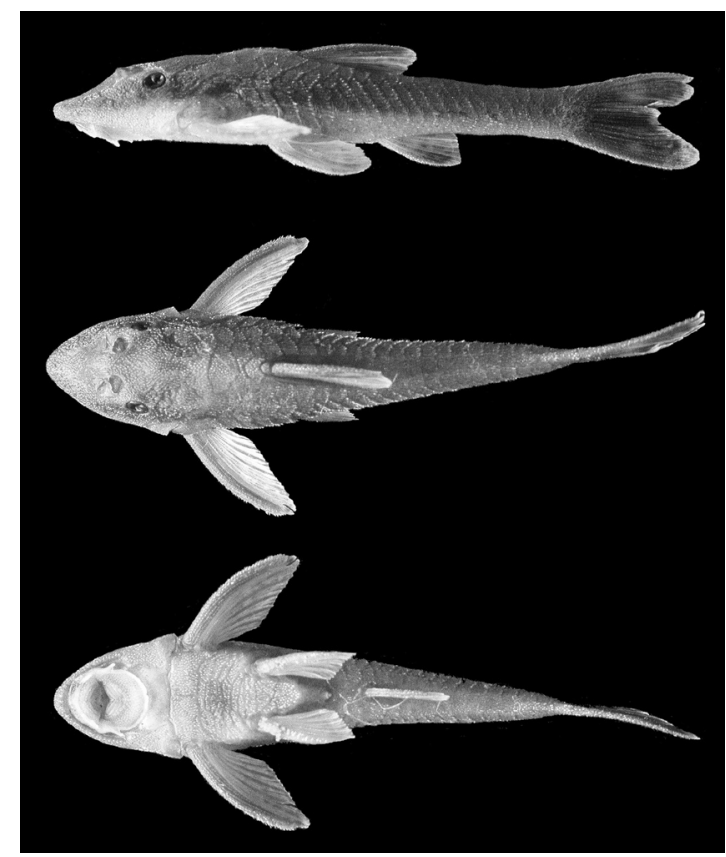

Figure 1. Hisonotus chromodontus, MZUSP 45322, $25.8 \mathrm{~mm}$ SL, Holotype

the farm house $\left(13^{\circ} 51^{\prime} \mathrm{S}\right.$ and $\left.56^{\circ} 20^{\prime} \mathrm{W}\right) ; 16$ February 2000; MZUSP Fish Section students - MZUSP 61045, 5, 12.0-27.4 mm SL, Nova Mutum, creek tributary of Rio Arinos, Fazenda Buriti, Igarapó; 20 February 2000; MZUSP Fish Section students - MZUSP 61115, 5, 16.3-27.0 mm SL, Nova Mutum, Rio Criquiri, tributary to Rio dos Patos; 16 February 2000; MZUSP Fish Section students - MZUSP 87143, 64, 6 C\&S, 16.3-32.5 mm SL - MCP 37636, 5, 25.4-32.5 mm SL - ANSP 180650, 5, 24.4-30.0 mm SL, Nortelândia, Rio Sumidouro Grande, at Fazenda Arrossensal; 6-11 November 2000; J.C. Garavello - MHNG 2653.044, 4, 17.5-20.8, neighborhood of Sinop; no date; U. Werner.

Diagnosis: Teeth reddish-brown tipped distinguishes this species from remaining species of the genus, which always have hyaline or slightly yellowish tipped teeth. It can also be distinguished by the combination of: 20-40 teeth on premaxillary and 15-38 on the dentary bones; 23-24 plates in longitudinal series; lateral line almost complete, represented by 19-22 perforated +1 or 2 nonperforated plates; dorsal surface of pectoral spine with about five longitudinal series of odontodes; abdomen in adults (about $23.0 \mathrm{~mm} \mathrm{SL}$ ) entirely covered with large plates, two to four in lateral series between the tip of the cleithrum and pelvic-fin base; a large dark brown lateral stripe extending from tip of snout, through inferior orbit, to end of caudal peduncle; transverse dark bars very inconspicuous or absent.

Description: Morphometric data presented in Table 1. Maximum body length $32.5 \mathrm{~mm}$ SL. Snout tip rounded; dorsal profile of body very concave from tip of snout to vertical through posterior margin of nostril; straight or slightly concave from that point to posterior 
Table 1. Morphometric characters of Hisonotus chromodontus, expressed as percents of standard length (2-7) and head length (8-11).

\begin{tabular}{lccccc}
\hline \multicolumn{1}{c}{ Characters } & Holotype & \multicolumn{3}{c}{ Paratypes (N = 31) } \\
\cline { 2 - 4 } & MZUSP & \multicolumn{2}{c}{ Range } & Mean & Standard deviation \\
\cline { 2 - 4 } & $\mathbf{4 5 3 5 5}$ & 16.3 & 30.3 & 24.49 & - \\
\cline { 2 - 4 } 1) Standard length (mm) & 25.8 & 15.95 & 19.64 & 18.04 & 0.0086 \\
2) Body depth & 18.22 & 23.93 & 28.21 & 25.93 & 0.0116 \\
3) Body width & 25.19 & 27.50 & 35.58 & 30.24 & 0.0193 \\
4) Head length & 29.46 & 45.36 & 52.00 & 48.08 & 0.0164 \\
5) Snout to dorsal-fin origin & 46.12 & 29.50 & 34.21 & 32.16 & 0.0138 \\
6) Caudal peduncle length & 31.40 & 7.98 & 10.00 & 9.26 & 0.0038 \\
7) Caudal peduncle depth & 9.30 & 13.79 & 17.24 & 15.42 & 0.0084 \\
8) Horizontal eye diameter & 15.79 & 65.52 & 72.46 & 69.77 & 0.0165 \\
9) Snout length & 69.74 & 36.21 & 48.61 & 44.34 & 0.0260 \\
10) Interorbital width & 46.05 & 8.62 & 14.29 & 11.24 & 0.0177 \\
11) Internares width & 11.84 & & & & \\
\hline
\end{tabular}

margin of supraoccipital, sometimes elevated (convex) on top of supraoccipital; straight from supraoccipital to dorsal-fin origin; straight at dorsal-fin base and straight or slightly convex from dorsal-fin end to near end of caudal peduncle. Ventral bony profile of head straight. Snout slightly pointed in dorsal view, its tip rounded. Dorsal surface of snout slightly depressed in front of each nostril but more or less prominent on median dorsal line between nostrils and along dorsal orbital rim.

Usually no tufts or crests of odontodes on head, sometimes small tuft of odontodes at posterior tip of supraoccipital.Ventral rostral margin of snout with strong and posteriorly directed odontodes, without naked area in front of snout between upper and lower odontodes; ill-defined series with numerous small odontodes on upper portion of head. Caudal peduncle at vertical through posterior tip of anal fin approximately rounded in cross section. Orbit small, latero-dorsally situated, its diameter 1.5-2.2 times in vertical distance between ventral rim of orbit and ventral margin of head.

Opening of air bladder capsule small, its depth less than one half of orbital diameter. Perforations of pterotic-supracleithrum distributed on whole bone, greater and more concentrated on its inferior margin; its openings nearly rounded in median region, and irregular along inferior and posterior margins of bone. Mouth small; oral disk nearly rounded, papillose, covering two thirds of distance from mandibulary ramus to scapular bridge when depressed; free tip of maxillary barbel as long as half orbital diameter or less; premaxillary teeth 20-40; dentary teeth 15-38. All teeth slender, bifid and with reddish-brown tip.

Dorsal-fin rays i,7; dorsal-fin origin located posteriorly to vertical through pelvic fin origin by a distance of about one orbital diameter. Pectoral-fin rays i,6; fin with posterior margin straight or slightly convex; pectoral spine reaches near tip of unbranched pelvic fin ray; pectoral spine with about five series of odontodes along its dorsal surface. Pelvic-fin rays i,5; posterior margin of pelvic fin slightly rounded; tip of adpressed pelvic fin reaching about mid-distance between anus and analfin origin. Anal-fin rays i,5; posterior margin straight. Caudal fin forked, with both lobes of same size and slightly pointed; principal caudal fin rays i,14,i.

Body covered with bony plates except on ventral part of head and very narrow areas surrounding pelvic fin bases and anus. Body plates uniformly covered by odontodes not arranged in rows. Supraoccipital posteriorly limited by only one plate, sometimes divided in two plates; this followed by pair of plates and azygous predorsal plate, immediately anterior to first dorsal-fin ray (lock). Dorsal fin-locking mechanism present. Longitudinal series with 23-24 plates; lateral line almost complete, with 19-22 perforated plus 1 or 2 no perforated plates.

Scapular bridge completely exposed or with very reduced median pair of arrector fossae. Abdomen in adults (about $23.0 \mathrm{~mm} \mathrm{SL}$ ) entirely covered with large plates; lateral abdominal series each with 2-5 large plates between tip of cleithrum and pelvic-fin base; 2 5 irregular series of plates between them. Single large posteriorly rounded plate in front of anus preceded by a few other large plates in front. First proximal radial of anal fin exposed as azygous plate in front of first anal-fin ray. Three plates on ventral series anterior to anal plate.

Color in alcohol: Large brown lateral stripe extending from tip of snout through inferior orbit to end of caudal peduncle; transverse dark brown bars very inconspicuous or absent. Body ground color light brown on dorsum, yellowish ventral under lateral stripe. Dorsal, pectoral, pelvic and anal fins with brown dots on rays, varying in concentration of chromatophores from one individual to another; inter-radial membranes hyaline. Caudal fin with dark brown chromatophores largely concentrated on rays and membranes, forming large blotch leaving hyaline or whitish variable areas 
at middle of both lobes and at narrow posterior area of fin border.

Sexual dimorphism: As in many other species of Hisonotus, the males of $H$. chromodontus have conspicuous urogenital papillae immediately posterior to anal opening, whereas in females the urogenital ducts open into the inner cloacal cavity. Adult males are additionally distinguished by modifications on the dorsal surface of the pelvic fin: 1) development of a characteristic skin flap along first ray (unbranched) and 2) greater development and typical arrangement of the odontodes of median portion of branched rays, which also show an enlargement of the skin covering those odontodes. In females there is no skin flap on the dorsal surface of the first ray (unbranched) and odontodes on the dorsal surface of branched rays are minute or absent.

Distribution: Upper Rio Tapajós drainage in Mato Grosso, Brazil.

Etymology: The species name chromodontus from Greek chroma (= color), and odontos (= tooth) refers to the reddish-brown tip of teeth of the new species.

Ecology: Hisonotus chromodontus was collected in flat areas in creeks of headwaters of Rio Tapajós in places of shallow clear waters with low current and sandy substrate; marginal vegetation represented mainly by grass in deforested areas. The holotype of the new species was collected in a creek severely altered by human activities; alongside a trail with very shallow water, the margin deprived of vegetation at the opposite side of a swampy area, where vegetation was mainly represented by Tipha and Grammineae.

\section{2. Hisonotus luteofrenatus, new species (Figure 2, Table 2)}

Holotype: MZUSP 62593, 28.3 mm SL, ㅇ; Brazil, Mato Grosso State, Sinop, Riacho Loanda, tributary of Rio Teles Pires, ca. 54 km north of Sinop on the BR-163 road to Santarém $\left(11^{\circ} 25^{\prime} \mathrm{S}\right.$ and $\left.55^{\circ} 21^{\prime} \mathrm{W}\right)$; 21 February 1998; M. I. Landim and C. Moreira.

Paratypes: Brazil, Mato Grosso State, Rio Arinos and Rio Teles Pires drainages: MZUSP 62590, 2, 22.2-29.9 mm SL, and MZUSP 87144, 13, 1 C\&S, 16.2$27.0 \mathrm{~mm}$ SL; same data as holotype - MZUSP 62594, 8, 1 C\&S, 22.4-30.5 mm SL, Sinop, Riacho Selma, ca. $38.4 \mathrm{~km}$ from Sinop, on the BR-163 road to Santarém (11 $34^{\prime} \mathrm{S}$ and $\left.55^{\circ} 21^{\prime} \mathrm{W}\right)$; 28 February 1998; M. I. Landim and C. Moreira - MZUSP 42458, 6, 24.325.0 mm SL, Rio Juína, km 31 on the Juína-Fontanilha road; 13 September 1989; S.O. Kullander - MHNG 2664.080, 3, 19.2-24.5, neighborhood of Sinop; no date; U. Werner.

Diagnosis: Distinguished from remaining species of genus, except $H$. insperatus, by the presence of a pair of rostral plates at tip of snout and from $H$. insperatus by the higher number of teeth on premaxillary (12-30) and dentary bones (9-26) vs. (3-14) and (5-11). It can be distinguished from other species of the genus by the following combination of features: $25-26$ plates on longitudinal series; lateral line almost complete with 23-24

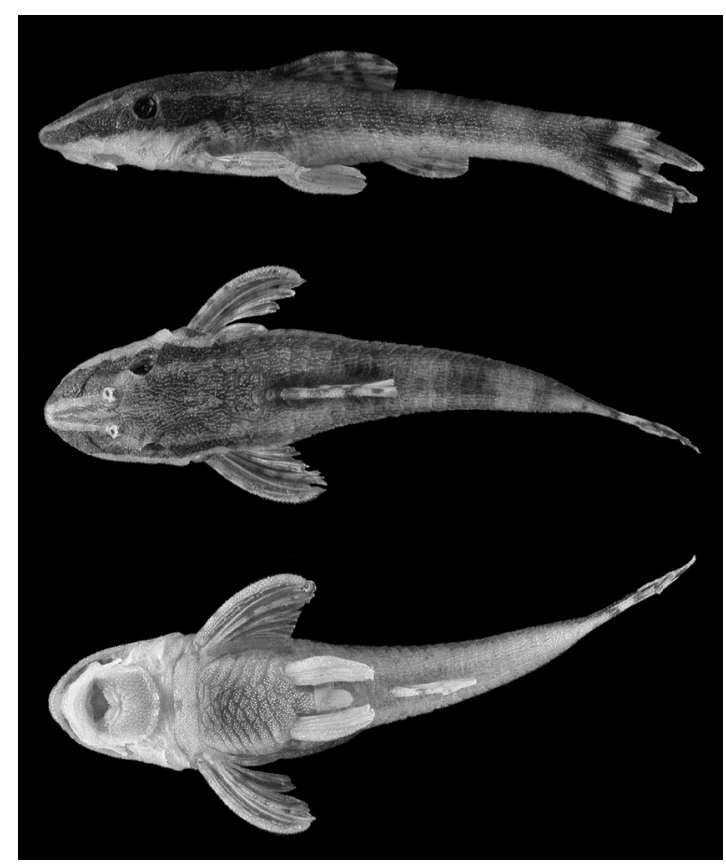

Figure 2. Hisonotus luteofrenatus, MZUSP 62593, $28.3 \mathrm{~mm}$ SL, Holotype.

perforated plus last non-perforated plates; abdomen in adults entirely covered with large plates, five to eight plates in lateral series between tip of cleithrum and base of pelvic fin; large dark brown lateral stripe extending from tip of snout to caudal blotch; dorsum with basal dark blotch near origin of dorsal-fin region and three transverse dark brown bars located at end of dorsal-fin base, middle and end of caudal peduncle; yellow line extending from anterior part of each orbit, over inferior nostrils, both converging to tip of snout.

Description: Morphometric data presented in Table 2. Maximum body length $30.5 \mathrm{~mm}$ SL. Dorsal profile of head slightly convex from tip of snout to dorsal-fin origin; usually slightly elevated in front of nostrils and at supraoccipital bone. Dorsal profile of trunk almost straight along base of dorsal fin and toward end of caudal peduncle. Ventral profile of head distinctly concave. Caudal peduncle ellipsoid in cross-section at vertical through posterior tip of anal fin. Head and snout slightly pointed in dorsal view, snout tip rounded; dorsal surface of snout slightly depressed in front of each nostril. No tufts or crests of odontodes on head; inferior rostral margin of snout with posteriorly directed odontodes, and without naked area in front of snout between upper and lower odontodes. Odontodes on upper part of head small, forming relatively well-defined diverging anterior and converging posterior series.

Orbit small, dorso-laterally situated, its diameter 1.5-1.7 times in vertical distance between ventral rim of orbit and ventral margin of head. Opening of air bladder capsule small, its depth about half of orbital diameter. Pterotic-supracleithrum with small perforations; opening of each perforation nearly rounded on median re- 
Table 2. Morphometric characters of Hisonotus luteofrenatus, expressed as percents of standard length $(2-7)$ and head length $(8-11)$.

\begin{tabular}{|c|c|c|c|c|c|}
\hline \multirow[t]{3}{*}{ Characters } & \multirow{3}{*}{$\begin{array}{c}\text { Holotype } \\
\text { MZUSP } \\
62593 \\
\end{array}$} & \multicolumn{4}{|c|}{ Paratypes $(\mathrm{N}=23)$} \\
\hline & & \multicolumn{2}{|c|}{ Range } & \multirow[t]{2}{*}{ Mean } & \multirow{2}{*}{$\begin{array}{l}\text { Standard } \\
\text { deviation }\end{array}$} \\
\hline & & Low & High & & \\
\hline 1) Standard length (mm) & 28.3 & 16.2 & 30.5 & 24.62 & - \\
\hline 2) Body depth & 16.61 & 15.43 & 19.63 & 17.94 & 0.0115 \\
\hline 3) Body width & 22.97 & 22.50 & 25.96 & 24.16 & 0.0091 \\
\hline 4) Head length & 28.62 & 28.85 & 33.33 & 30.82 & 0.0119 \\
\hline 5) Snout to dorsal-fin origin & 44.17 & 45.00 & 50.62 & 47.01 & 0.0141 \\
\hline 6) Caudal peduncle length & 28.62 & 25.31 & 31.58 & 28.04 & 0.0189 \\
\hline 7) Caudal peduncle depth & 8.83 & 8.98 & 10.20 & 9.50 & 0.0030 \\
\hline 8) Horizontal eye diameter & 16.05 & 15.07 & 18.18 & 16.51 & 0.0080 \\
\hline 9) Snout length & 71.60 & 67.09 & 75.38 & 69.80 & 0.0201 \\
\hline 10) Interorbital width & 41.98 & 36.36 & 45.45 & 40.04 & 0.0212 \\
\hline 11) Internares width & 13.58 & 9.72 & 15.38 & 12.95 & 0.0148 \\
\hline
\end{tabular}

gion, and irregular along inferior and posterior margins of bone.

Dorsal-fin rays i,7; dorsal fin origin located in vertical through pelvic-fin origin or slightly anterior of it. Pectoral-fin rays i,6; fin with posterior margin straight; pectoral spine reaches middle length of unbranched pelvic-fin ray; pectoral spine smooth and lacking odontodes along its posterior dorsal margin for distance of more than one-third of its width. Pelvic-fin rays i,5; posterior margin of pelvic fin slightly rounded; tip of adpressed pelvic fin extends to anal fin origin in males, but falls short of that point in females. Anal-fin rays i,5; fin margin straight posteriorly. Caudal fin emarginated, with both lobes slightly pointed; principal caudal-fin rays i,14,i.

Body covered with bony plates except on ventral part of head and very narrow areas surrounding pelvic fin bases and anus. Body plates uniformly covered by odontodes arranged into somewhat regular longitudinal rows. Tip of snout covered by pair of rostral plates (Figure 3). Supraoccipital bone posteriorly limited by one plate on each side and by one median dorsal azygous plate, posteriorly followed by one pair of plates and azygous predorsal plate immediately anterior of dorsal fin. Plates of longitudinal series 25-26; lateral line continuous, uninterrupted by gaps and almost complete, with 23-24 perforated plus 1 or 2 non-perforated terminal plates. Mouth small; oral disk approximately rounded, papillose with posterior margin of disk almost reaching scapular bridge when depressed; maxillary barbel slightly smaller than orbital diameter; premaxillary teeth 12-30 and dentary teeth 9-26. All teeth slender and bifid.

Color in alcohol: Body ground color yellowish. Dorsal surface of head brown, except for yellow line extending from anterior dorsal region of each orbit, over inferior nostrils, both converging to tip of snout; each one of these lines conspicuously or inconspicuously extending posteriorly over dorsal rim of orbit, pterotic bone and anterior body plates of mid-dorsal series.

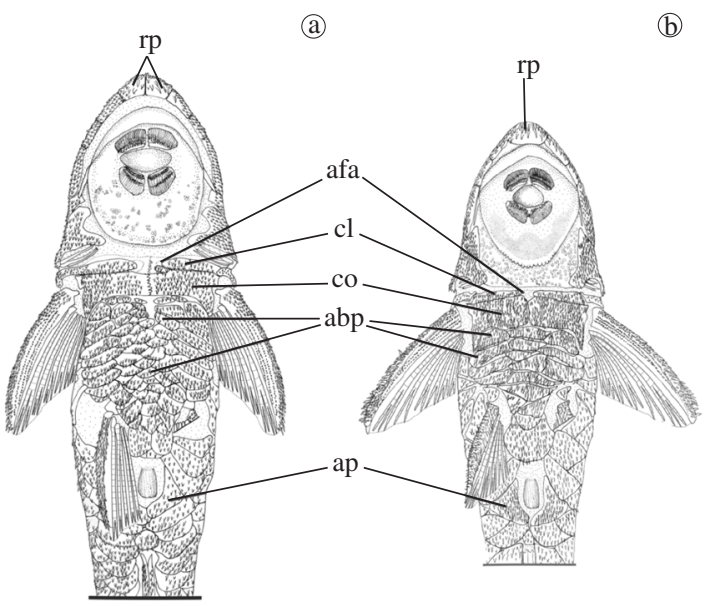

Figure 3. a) Hisonotus chromodontus, paratype MZUSP 45315 (C\&S), $26.7 \mathrm{~mm} \mathrm{SL}$; and b) Hisonotus luteofrenatus, paratype MZUSP 62594 (C\&S), $26.6 \mathrm{~mm}$ SL. Anterior ventral portion of body showing rostral plates (rp); arrangement of abdominal plates (abp); small arrector fossae aperture (afa); cleithrum (cl); coracoid (co); anal plate (ap).

Longitudinal stripe extends from tip of snout through eye and body also to blotch at base of caudal fin and continues for some distance on median caudal-fin rays. Three broad transverse brown bars on dorsum extending ventrally to longitudinal stripe. First bar just behind base of dorsal fin, third on posterior portion of caudal peduncle, and second between them. Brownish area around anterior dorsal-fin base. Dorsal fin with chromatophores on rays somewhat concentrated at regular intervals to form two or three dark spots along rays. Unbranched pectoral fin ray brownish. Branched pectoral-, pelvic-, and analfin rays with some chromatophores, sometimes concentrated in spots; inter-radial membranes yellowish or hyaline. Caudal fin with dark brown chromatophores largely 
concentrated on rays and membranes, leaving hyaline or whitish variable areas on upper and lower portions of caudal peduncle and middle of both lobes, as well as in narrow posterior border of fin.

Sexual dimorphism: Males of Hisonotus luteofrenatus have conspicuous urogenital papillae, immediately posterior to anal opening, whereas in females the urogenital duct opens into the inner cloacal cavity. Adult males are additionally distinguished by the longer pelvic fin extending beyond anal-fin origin, by the development of a skin flap along dorsal portion of first pelvicfin ray and by the growth of skin along dorsal surface of branched rays concealing specialized odontodes. In females the tip of pelvic fin falls short of anal-fin origin, there is no skin flap on first pelvic-fin ray and no growth of skin and odontodes on dorsal surface of the pelvic-fin rays are smaller.

Distribution: Upper Rio Tapajós basin in Mato Grosso State (Figure 4).

Etymology: The species name luteofrenatus from the Latin luteo (= yellow), and frenatus (= with bridle), refers to the yellow pair of lines running dorsally on head from tip of snout to dorsal rim of orbit.

Ecology: Hisonotus luteofrenatus was collected in flat areas in creeks of headwaters of the Rio Tapajós in places of shallow clear waters with low current and sandy substrate; marginal vegetation represented mainly by grass in deforested areas.

\section{Discussion}

At first sight, coloration of tip of teeth in Loricariidae could be interpreted as a physiological feature that could change according to the kind of food the individuals ingest, characteristics of the water they live in, etc. However, in more than one hundred specimens of Hisonotus chromodontus examined, varying from 12.0 to $32.2 \mathrm{~mm} \mathrm{SL}$, the teeth are reddish-brown tipped; besides, they were collected in six different creeks, some of which quite distant from one another in tributaries of Rio Teles Pires and Rio Arinos, in the Rio Tapajós basin (Figure 4). On the other hand, in specimens of Hisonotus luteofrenatus (MZUSP 62590 and 62593) syntopic with Hisonotus chromodontus (MZUSP 70758), which are living in similar environmental conditions, the tips of teeth are not reddish-brown, but hyaline or light yellow. We have also examined the teeth of many species of Hisonotus deposited in MZUSP collections (see list of comparative material examined), as well as species of other genera of Hypoptopomatinae and found that they always have the tip of the teeth hyaline or light yellow. The reddish brown tooth tip of Hisonotus chromodontus is a unique feature within the genus Hisonotus and maybe within all the Hypoptopomatinae.

The number of teeth on the premaxillary and dentary bones usually is a good character to diagnose Hypoptopomatine species, but since it varies greatly with growth, the character has to be used taking into account the ontogenetic variation. We present the distribution of premaxillary (Figure 5) and dentary (Figure 6) teeth according to size of the specimens and it can be seen that specimens of $H$. luteofrenatus and $H$. insperatus within the same size range have clear differences in counts.

The growth of skin as well as size of odontodes on the dorsal surface of pelvic-fin rays is herein assigned for the first time in males of the Hisonotus species. This kind of dimorphism is probably widespread among Hisonotus species, but it has been overlooked in other species where the character is less conspicuous than in the two new species herein described.

We are describing the two new species in the genus Hisonotus but the definition and relationships of this genus are not entirely resolved. The first character to diagnose the genus Hisonotus refers to snout plates anterior to the anterior nostril margin "reduced or absent, yielding a large, paired un-plated region between the rostrum and nostril on either side of the midline" (Schaefer, 1998, p. 387). Although H. chromodontus and $H$. luteofrenatus do not present this feature, examination of other species of the genus revealed that this character is quite variable. For example, in H. notatus, type species of the genus, plates are reduced or absent in some specimens, but well-developed in the region between the rostrum and nostril on either side of the midline in some other speciments (see comments in Britski and Garavello, 2003). The second character used by Schaefer (op. cit.) "rostrum with enlarged odontodes, plates forming the lateral rostral margins thickened" although present in the new species herein described, is also present in other Hypoptopomatinae taxa (as for example Parotocinclus), and cannot be considered exclusive to Hisonotus.

Another character used by Schaefer (1998) when reanalyzing the Hypoptopomatinae refers to the truncation of the median plate series and according to that author, in Hisonotus the median plate series terminates anterior to the caudal fin such that the last two plates of the dorsal and ventral series touch each other along the midline. However, this character also proved to vary within the genus, especially in $H$. notatus its type species (see Britski and Garavello, 2003:592).

On the other hand, $H$. luteofrenatus as well as H. insperatus Britski and Garavello, two species very similar to one another, present a peculiar feature within Hisonotus, the snout tip is covered by a pair of plates (Figure 3) as opposed to the situation for other members of the genus in which the snout tip is covered by a single plate.

We have also demonstrated that another character used by Schaefer to define the genus Parotocinclus (basipterygium solid anteriorly) is not satisfactory (see Britski and Garavello, 2002, p. 286).

These observations show that the genus Hisonotus, as well as other genera of the Hypoptopomatinae, need to be redefined. Thus we prefer to describe the new species in the genus Hisonotus, until a more thorough phylogenetic analysis of the group is carried out. 


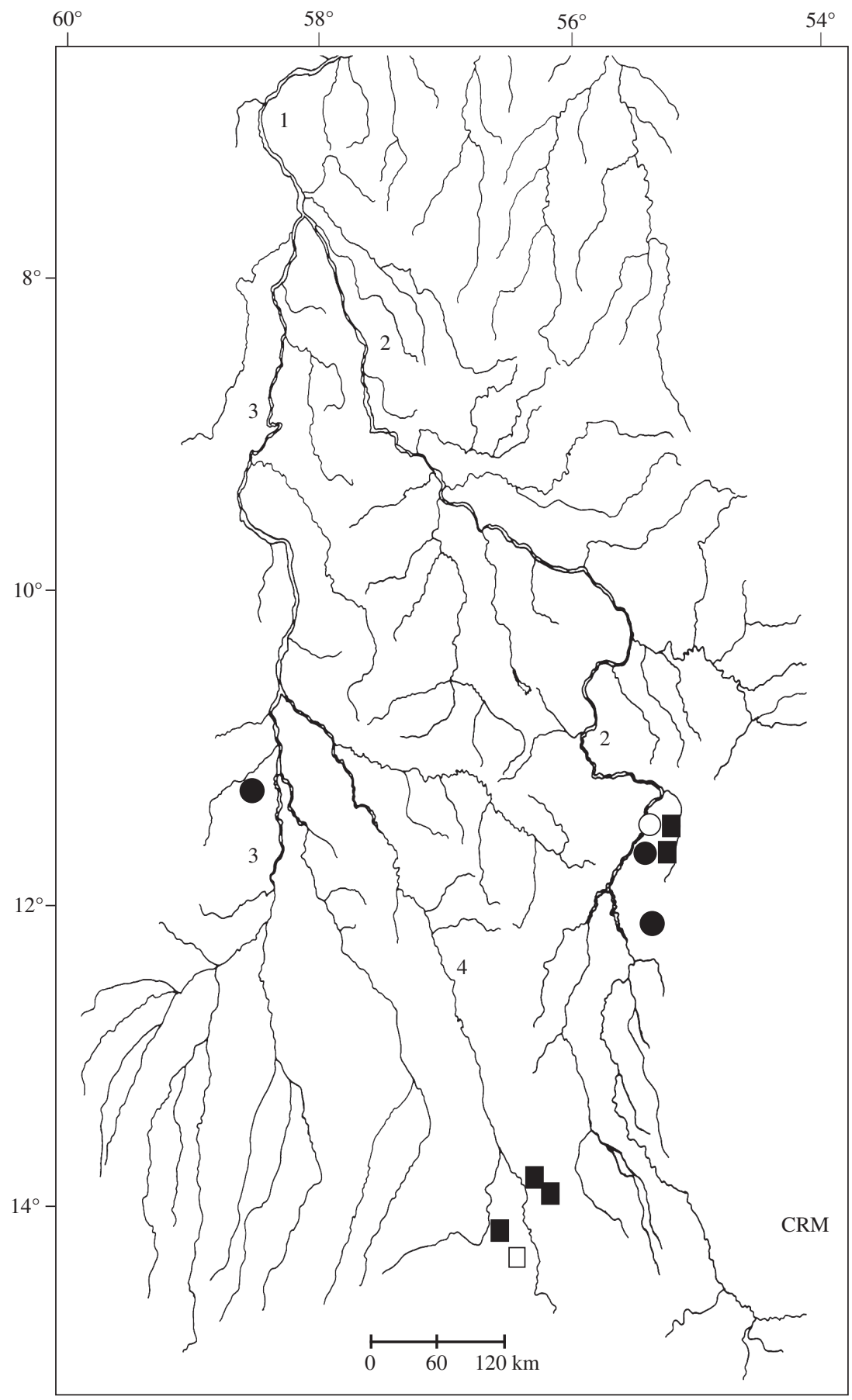

Figure 4. Upper Rio Tapajós drainage, Mato Grosso State, Brazil, showing distribution of Hisonotus chromodontus (square) and Hisonotus luteofrenatus (circle), type localities are open symbols. Symbols may represent more than one sample. Main rivers: Rio Tapajós (1); Rio Teles-Pires (2); Rio Juruena (3); Rio Arinos (4).

Comparative material: Brazil: Hisonotus insperatus: MZUSP 78957, holotype; MZUSP 78958, paratypes, São Paulo: Botucatu, Rio Capivara, Rio Tietê drainage. Hisonotus laevior: MZUSP 25024, 5, Rio Grande do Sul: Rio Forqueta, Marques de Souza, Município de Lageado. Hisonotus leucofrenatus: MZUSP 8585-8608,
24 (3 C\&S), São Paulo: Ribeirão Poço Grande, Juquiá. Hisonotus nigricauda: MZUSP 8668, 22 (10 C\&S), Rio Grande do Sul: Rio dos Sinos, São Leopoldo. Hisonotus notatus: MZUSP 10317, 28 (4 C\&S), Rio de Janeiro: Rodovia Rio de Janeiro - Santa Cruz, km 59, Jardim Palmares. Microlepidogaster depressinotus: MZUSP 


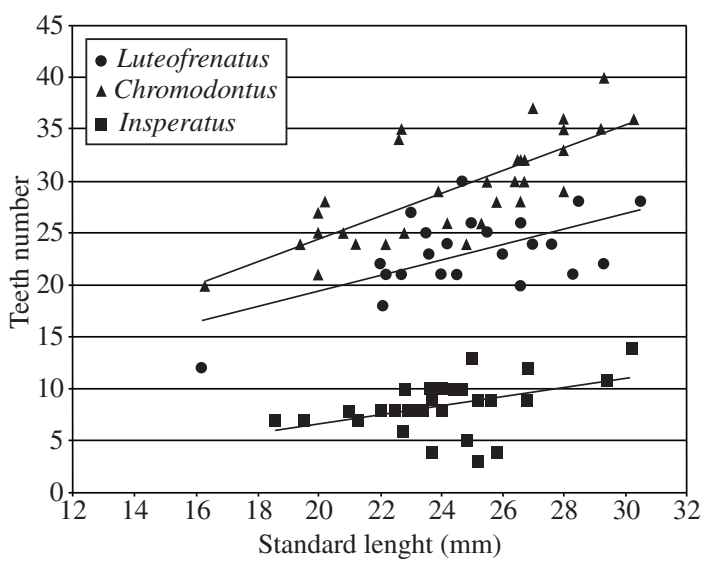

Figure 5. Distribution of premaxillary teeth number as function of standard length in three species of Hisonotus.

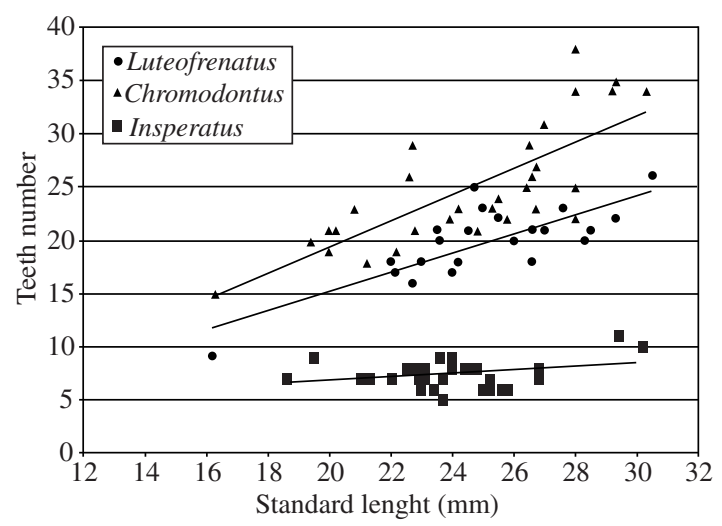

Figure 6. Distribution of dentary teeth number as function of standard length in three species of Hisonotus.

2156, holotype, São Paulo: Piracicaba. Otocinclus francirochai: MZUSP 3258, lectotype; MZUSP 53875397, 11, paralectotypes, São Paulo: Creeks by Pirangi, tributary of Rio Turvo. Otocinclus depressicauda: MZUSP 1004, lectotype; MZUSP 5381-5384, 4, paralectotypes, São Paulo: Sorocaba. Otocinclus paulinus: BMNH 1907.7.6.9, type, São Paulo: Piracicaba.

Uruguay: Hisonotus ringueleti: MZUSP 62788, paratypes, Rivera State, upper Uruguay river basin, Quaraí river drainage, creek at km 18 of route joining
Santana do Livramento, Brazil, and Rivera, Uruguay (ca. $31^{\circ} 00^{\prime} \mathrm{S}$ and $55^{\circ} 30^{\prime} \mathrm{W}$ ).

Argentina: Hisonotus maculipinnis: MZUSP 22324, 25, Santa Fe: Cayasta, no date.

Acknowledgments - We are very indebted to Naércio A. Menezes for reading the manuscript and providing helpful comments. Cristiano Moreira and Maria Isabel Landin collected most of the specimens of the two new species, and provided ecological data. Alberto Akama and José L. Birindelli helped with the figures and map. Flavio C. T. Lima helped with the management of the fish collection. Eduardo G. Baena drew figure 3. For loan of specimens we are thankful to Claude Weber and Sonia Muller from MHNG. Research funding for both authors is provided by the Conselho Nacional de Desenvolvimento Científico e Tecnológico (CNPq). The Smithsonian Institution supported fieldwork in October 1992.

\section{References}

BRITSKI, HA. and GARAVELLO, JC., 1984. Two new southeastern Brazilian genera of Hypoptopomatinae and a redescription of Pseudotocinclus Nichols, 1919 (Ostariophysi, Loricariidae). Pap. Avuls. Zool., São Paulo, vol. 35 no. 21, p. 225-241.

-, 2002. Parotocinclus jumbo, a new species of the subfamily Hypoptopomatinae from northeastern Brazil (Ostariophysi: Loricariidae). Ichthyol. Explor. Freshwaters, vol. 13, no. 3, p. 279-288.

-, 2003. Hisonotus insperatus, new species, from the upper Rio Paraná Basin (Pisces: Ostariophysi: Loricariidae). Copeia 2003, no. 3, p. 588-593.

LEVITON, AE., GIBBS JR., RH., HEAL, E. and DAWSON, CE., 1985. Standards in herpetology and ichthyology: Part I. Standard symbolic codes for institutional resources collections in herpetology and ichthyology. Copeia 1985, no. 4, p. 802-832.

SCHAEFER, SA., 1997. The Neotropical cascudinhos: Systematics and biogeography of the Otocinclus catfishes (Siluriformes:Loricariidae). Proc. Acad. Nat. Sci., Philadelphia, vol. 148, p. 1-120.

-, 1998. Conflict and resolution: Impact of new taxa on phylogenetic studies of the neotropical cascudinhos (Siluroidei: Loricariidae), p. 375-400. In MALABARBA, LR., REIS, RE., VARI, RP., LUCENA, ZE. and LUCENA, CA. (eds). Phylogeny and classification of Neotropical fishes. EDIPUCRS, Porto Alegre, Brasil.

-, 2003. Subfamily Hypoptopomatinae (armored catfishes) p. 321-329. In REIS, RE., KULLANDER, SO. and FERRARIS Jr., CJ. (eds.). Checklist of Freshwater Fishes of South and Central America. EDIPUCRS, Porto Alegre, Brasil, 729p. 